\title{
Comparative Bioavailability: Two Pramipexole Formulations in Healthy Volunteers after a Single Dose Administration under Fasting Conditions
}

Eduardo Abib Jr ${ }^{1,2 *}$, Luciana Fernandes Duarte ${ }^{2}$ and Renata Pereira ${ }^{2}$

${ }^{1}$ Department of Clinical Medicine, Faculty of Medical Sciences, State University of Campinas (UNICAMP), 13083-970, Campinas, SP, Brazil

${ }^{2}$ Scentryphar Clinical Research, 13020-420, Campinas, SP, Brazil

\begin{abstract}
The study was performed to compare the bioavailability of two Pramipexole $0.125 \mathrm{mg}$ tablet formulations: the test formulation was pramipezan ${ }^{\circledR}$ (pramipexole) manufactured by Cobalt Pharmaceuticals, Canada/ Arrow Farmacêutica Ltda*. Sifrol ${ }^{\circledR}$ (Pramipexole) from Boehringer Ingelheim do Brasil Química e Farmacêutica Ltda was used as reference formulation. The study was conducted open with randomized two period crossover design and 8 days wash out period in 48 volunteers of both sexes. Plasma samples were obtained over a 48 hour interval. Pramipexole was analyzed by LC-MS-MS in the presence of Tansulosina as internal standard. The mean ratio of parameters $\mathrm{C}_{\max }$ and $A \cup \mathrm{C}_{0 . t}$ and $90 \%$ confidence intervals of correspondents were calculated to determine the bioequivalence. The means AUC for test and reference formulation were $8201.90 \mathrm{pg} . \mathrm{h} / \mathrm{mL}$ and $7891.56 \mathrm{pg} . \mathrm{h} / \mathrm{mL}$, for $\mathrm{AUC}_{0-\infty}$ were $8574.71 \mathrm{pg} . \mathrm{h} / \mathrm{mL}$ and $8288.01 \mathrm{pg} . \mathrm{h} / \mathrm{mL}$ and, for $\mathrm{C}_{\max } 642.09 \mathrm{pg} / \mathrm{mL}$ and $633.94 \mathrm{pg} / \mathrm{mL}$, respectively. Geometric mean of pramipezan ${ }^{\circledR}$ (pramipexole) $/$ Sifrol $^{\otimes} 0.125 \mathrm{mg}$ individual percent ratio was $103.61 \%$ AUC $103.13 \%$ for $A \cup C_{0-\infty}$ and $100.81 \%$ for $C_{\text {max }}$. The $90 \%$ confidence intervals were $98.02-109.51 \%, 97.95-108.59 \%$, $93.06-109.21 \%$, respectively. Since the $90 \%$ confidence intervals for $C_{\max }, A \cup C_{0-1}$ and $A \cup C_{0-\infty}$ were within the $80-$ $125 \%$ interval proposed by Food and Drug Administration, it was concluded that Pramipezan ${ }^{\circledR}$ (pramipexole) 0.125 $\mathrm{mg}$ tablet was bioequivalent to Sifrol ${ }^{\circledR} 0.125 \mathrm{mg}$ tablet according to both the rate and extent of absorption.
\end{abstract}

Keywords: Bioavailability; Pharmacokinetics; Chromatography; Bioequivalence; Pramipexole

\section{Introduction}

Parkinson's disease, neurodegenerative disease the central nervous system affecting the substantia nigra, component of the basal ganglia that requires regular medication unlimited in time. The disease is named after the English doctor James Parkinson, who published the first in An Essay on the Shaking Palsy. The motor symptoms of disease result from the death of dopamine-generating cells in the substantia nigra, a region of the midbrain; the cause of this cell death is unknown. Most people with Parkinson's disease have idiopathic Parkinson's disease. A small proportion of cases, however, can be attributed to known genetic factors. Other factors have been associated with the risk of developing Parkinson's, but no causal relationship has been proven. Early in the course of the disease, the most obvious symptoms are movement-related; these include rigidity, shaking, slowness of movement and difficulty with walking and gait. Later, cognitive and behavioural problems may arise. Dementia commonly occurring in the advanced stages of the disease. Other symptoms include sleep, sensory and emotional problems. Parkinson's disease is more common in the elderly, with most cases after the age of 50 [1-4].

Modern treatments are effective at managing the early motor symptoms of the disease, mainly through the use of dopamine agonists. Pramipexole is a non-ergoline dopamine agonist indicated for treating early-stage Parkinson's disease and restless legs syndrome.

Pramipexole is a nonergot dopamine agonist with high relative in vitro specificity and full intrinsic activity at the $\mathrm{D}_{2}$ subfamily of dopamine receptors, binding with higher affinity to $\mathrm{D}_{3}$ than to $\mathrm{D}_{4}$ or $\mathrm{D}_{2}$ receptor subtypes. The precise mechanism of action of pramipexole as a treatment for Parkinson's disease is unknown, although it is believed to be related to its ability to stimulate dopamine receptors in the striatum. This conclusion is supported by electrophysiologic studies in animals that have demonstrated that pramipexole influences striatal neuronal firing rates via activation of dopamine receptors in the striatum and the substantia nigra. The relevance of $\mathrm{D}_{3}$ receptor binding in Parkinson's disease is unknown. Studies suggest that pramipexole might provide neuroprotective effects through depression of dopamine metabolism, stimulation of trophic activity and antioxidant effects. Pramipexole's demonstrated clinical efficacy for successful treatment in early disease for several years in the absence of L-dopa and as adjunctive therapy with L-dopa in late disease suggests a potential new paradigm for treatment of Parkinson's disease [5].

Pramipexole is metabolized by the liver. Pramipexole displays linear pharmacokinetics over the clinical dosage range and do not differ between men and women. Its terminal half-life is about 8 hours in young healthy volunteers. Pramipexole is rapidly absorbed, reaching peak concentrations in approximately 2 hours. The absolute bioavailability of pramipexole is greater than $90 \%$, indicating that it is well absorbed. Food does not affect the extent of pramipexole absorption, although the time of maximum plasma concentration is increased by about 1 hour when the drug is taken with a meal. Pramipexole appears to be the major circulating species in plasma [6,7].

The objective of this study was to compare in healthy volunteers, the pharmacokinetics profiles and evaluate the bioequivalence of one test formulation of $0.125 \mathrm{mg}$ tablet of Pramipezan ${ }^{\circledR}$ (pramipexole) manufactured by Cobalt Pharmaceuticals, Canada/ Arrow Farmacêutica Ltda. The test formulation was compared to $0.125 \mathrm{mg}$

*Corresponding author: Eduardo Abib Junior, Scentryphar Clinical Research, 885, Barão de Itapura ave, Campinas, 13020-420, SP, Brazil., Tel: (19)-3232 6350; Fax: (19)-3231-6715; E-mail: eabib@scentryphar.com

Received April 03, 2012; Accepted May 26, 2012; Published May 28, 2012

Citation: Abib E Jr, Duarte LF, Pereira R (2012) Comparative Bioavailability: Two Pramipexole Formulations in Healthy Volunteers after a Single Dose Administration under Fasting Conditions. J Bioequiv Availab 4: 056-059. doi:10.4172/jbb.1000113

Copyright: @ 2012 Abib E Jr, et al. This is an open-access article distributed under the terms of the Creative Commons Attribution License, which permits unrestricted use, distribution, and reproduction in any medium, provided the original author and source are credited. 
of Pramipexole (Sifro ${ }^{\circledR)}$ by Boehringer Ingelheim do Brasil Química e Farmacêutica Ltda (reference formulation).

\section{Methods}

\section{Study protocol}

The study was performed in accordance with the Helsinki Declaration and Good Clinical Practice Guideline, and informed consent was obtained from participants prior to study commencement. The clinical part of the study was conducted at Scentryphar Clinical Research (Campinas City, São Paulo, Brazil) and the bioanalytical part at Instituto de Ciências Farmacêuticas de Estudos e Pesquisas/ICF. (Goiânia City, Goiás, Brazil).

\section{Subjects}

Twenty eight healthy volunteers of both sexes (14 males and 14 females) who were between the ages of 22 and 49 (mean \pm SEM: $31.64 \pm$ 9.02 years), who had heights between $157.00 \mathrm{~cm}$ and $187.00 \mathrm{~cm}(168.00$ $\pm 0.09 \mathrm{~cm})$, and who weighed between $51.00 \mathrm{~kg}$ and $96.50 \mathrm{~kg}(68.74 \pm$ $11.65 \mathrm{~kg}$ ) and within $15 \%$ of their ideal body weight were enrolled in the study. Subjects were judged eligible for enrolment in this study if they were in compliance with all the inclusion and exclusion criteria described in the protocol.

All the subjects provided written informed consent to participate after explaining the nature and purpose of the study. The study protocol was approved by the University of Campinas/Unicamp with the ethical principles described in the Declaration of Helsinki, guidelines for International Conference on Harmonization-Good clinical practices (ICH-GCP).

All volunteers were healthy as assessed by physical examination, ECG, and the following laboratory tests: parasitological, blood glucose, urea, creatinine, uric acid, AST, ALT, alkaline phosphatase, Gamma GT, total bilirrubin, albumin and total protein, triglycerides, total cholesterol, hemoglobin, hematocrit, total and differential white cell counts and routine urine. All subjects were negative for HIV, HBV (except for serological scare) and HCV.

\section{Drug products}

The test formulation employed was Pramipezan $^{\circledR}$ (pramipexole) $0.125 \mathrm{mg}$ tablet (lot number ZB48) and the reference formulation was: Sifrol ${ }^{\circledR} 0.125 \mathrm{mg}$ tablet (lot number 6533).

\section{Study design}

The study was performed to compare the bioavailability of two Pramipexole $0.125 \mathrm{mg}$ tablet formulations under fasting conditions: the test formulation was Pramipezan ${ }^{\circledR}$ (pramipexole). Sifrol ${ }^{\circledR}$ from Boehringer Ingelheim do Brasil Química e Farmacêutica Ltda was used as reference formulation. The formulation was tested for bioequivalence for the first time.

The study was conducted in an open randomized 2 period crossover balanced design with 8 days wash out period between the doses. During each period, the volunteers were hospitalized at 8:00 pm having already had a normal evening meal, and after an overnight fast they received at 7:00 am a single $0.125 \mathrm{mg}$ tablet Pramipexole dose of either formulation. Water $(200 \mathrm{~mL})$ was given immediately after drug administration. All volunteers were then fasted 05 hours following the drug administration, after which a standard lunch was consumed and an evening meal was provided 10 hours after dosing. No other food was permitted during the "in-house" period. Liquid consumption was permitted ad libitum after lunch but xanthine-containing drinks including tea, coffee and cola were avoided. Systolic and Diastolic arterial pressure (measured on invasively with a sphygmomanometer automatic by Omron equipment), heart rate and temperature were recorded just before and hourly after drug administration.

Blood samples $(06 \mathrm{~mL})$ from a suitable antecubital vein were collected into EDTA containing tubes before and $0.15,0.30,0.45,1.00$, $1.20,1.40,2.00,2.20,2.40,3.00,3.20,3.40,4.00,4.30,5.00,6.00,8.00$, $10.00,12.00,14.00,24.00,48.00$ hours after administration of each Pramipexole $0.125 \mathrm{mg}$ tablet.

\section{Drug analysis}

Blood samples were cooled in a bath and centrifuged at 3.000 $\mathrm{rpm}$ for at least $10 \mathrm{~min}$ at approximately $4^{\circ} \mathrm{C}$. At least $3 \mathrm{~mL}$ of plasma were dispensed into polypropylene tubes. Sample tubes were frozen at $-20^{\circ} \mathrm{C}$, and maintained to that temperature until analysis (delivery to the analytical phase). All samples from a single volunteer were analyzed on the same day in order to avoid inter assay variation.

Plasma concentrations of Pramipexole were determined by the HPLC coupled with tandem mass spectrometry (LC/MS/MS), in positive ion electrospray ionization mode, using a multiple monitoring (MRM) method and isotopic labeled Tansulosina as internal standard (IS). The transitions used were $212.20 \rightarrow 153.00$ for Pramipexole and $409.00 \rightarrow 228.00$ for IS. This apparatus consisted of an Agilent 1200 Series pump and API 5000 mass spectrometer. Were the analytes extracted from plasma using on liquid - liquid extraction. The method was validated for selectivity, linearity, precision, accuracy, extraction recovery and stability. The analytical column was a ACE 5 AQ (150 x $4.6 \mathrm{~mm}$ ). The mobile phase used was a mixture of Buffer (ammonium acetate $2 \mathrm{mM})$ and methanol $(30: 70 \mathrm{v} / \mathrm{v})$, containing $0.025 \%$ formic acid.

\section{Pharmacokinetic analysis and statistical analysis}

The first-order terminal elimination rate constant (Ke) was estimated by linear regression from the points describing the elimination phase on a log-linear plot, using the software SAS ${ }^{\circledR}$ Institute (Version 9.1.3). Elimination half-life $\left(\mathrm{T}_{1 / 2}\right)$ was derived from this rate constant $\left(\mathrm{T}_{1 / 2}=\ln (2) / \mathrm{Ke}\right)$. The maximum observed plasma concentration $\left(\mathrm{C}_{\max }\right)$ and the time taken to achieve this concentration $\left(\mathrm{T}_{\max }\right)$ were obtained directly from the curves. The areas under the Pramipexole metabolite plasma concentration versus time curves from 0 to 48 hours $\left(\mathrm{AUC}_{0-48 \mathrm{~h}}\right)$ were calculated by applying the linear trapezoidal rule. Extrapolation of these areas to infinity $\left(\mathrm{AUC}_{0-\infty}\right)$ was done by adding the value $\mathrm{C} 48 / \mathrm{Ke}$ to the calculated $\mathrm{AUC}_{0-48 \mathrm{~h}}$ (where $\mathrm{C} 48=$ plasma concentration calculated from the log-linear regression equation obtained for the estimation of Ke 48 hours after dose).

The bioequivalence between both formulations was assessed by calculating individual $\mathrm{C}_{\max }, \mathrm{AUC}_{0-48 \mathrm{~h}}, \mathrm{AUC}_{0-\infty}$ and $\mathrm{C}_{\max } / \mathrm{AUC}_{0-48 \mathrm{~h}}$ ratios (test/reference) together with their mean and $90 \%$ confidence intervals (CI) after log transformation of the data. The inclusion of the $90 \% \mathrm{CI}$ for the ratio in the $80 \%$ to $125 \%$ range was analyzed by nonparametric (SAS ${ }^{\circledR}$ Institute Version 9.1.3) and parametric (ANOVA) methods.

\section{Results}

\section{Tolerability analysis}

Pramipexole was well tolerated at the administered dose in most volunteers. All the biochemical parameters did not any clinical relevant alterations. There was one serious adverse event, which is classified 
as likely to be related to study drug (convulsion). Procedures were carried out to the volunteer monitoring and reporting of adverse event responsible institutions.

\section{Method validation}

The calibration curves were linear in the ranges of $20-5000 \mathrm{pg} /$ $\mathrm{mL}(\mathrm{R} 2 \geq 0,99)$ by using least square linear regression analysis with a weight factor of $1 / x$. The precision and accuracy were obtained by the analysis of tree batches of QC samples (LLOQ, low, medium and High QCs) and the intra and inter day RSDs were no more than $17.4 \%$, indicating acceptable precision and accuracy of the present method.

The extraction recoveries of Pramipexole and IS from human plasma were $72.00 \%$ and $87.20 \%$, respectively. The stability of stock solutions of Pramipexole and IS were accessed and found stable at room temperature for $6 \mathrm{~h} 30 \mathrm{~min}$ and at $4^{\circ} \mathrm{C}$ for 15 days. The analytes in plasma stored at room temperature for $7 \mathrm{~h}$, at $4^{\circ} \mathrm{C}$ for 15 days, at $-20^{\circ} \mathrm{C}$ for 57 days and during the three freeze and thaw cycles indicated the good stability of Pramipexole and IS during the study.

\section{Pharmacokinetic and statistical analysis}

The mean $( \pm \mathrm{SD})$ plasma concentration time profile of the 2 formulations, shown in Figure 1, was similar and super imposable.

Central and dispersion measures for all pharmacokinetic parameters for both formulations are shown in Table 1 and Table 2. From this, the mean values of $\mathrm{C}_{\max }$ were found to be $633.94( \pm 110.99$ standard deviations [SD]) pg/mL for the reference product and 642.09 $( \pm 122.89) \mathrm{pg} / \mathrm{mL}$ for the test product. For $\mathrm{T}_{\max }(\mathrm{h})$, the mean values were found to be similar for both the reference and test product and the value was $2.33(3.00) \mathrm{h}$. The mean values of $\mathrm{AUC}_{0-48}$ were found to be $7891.56( \pm 1684.24) \mathrm{pg} . \mathrm{h} / \mathrm{mL}$ for reference and $8201.90( \pm 2059.40)$ $\mathrm{pg} . \mathrm{h} / \mathrm{mL}$ for the test product. The mean $\mathrm{AUC}_{0-\infty}$ was found to be $8288.01( \pm 1712.74)$ pg.h $/ \mathrm{mL}$ and $8574.71( \pm 2178.54)$ pg.h $/ \mathrm{mL}$ for the reference and the test product, respectively.

Table 3 presents the ratios and the respective confidence intervals for bioequivalence analysis.

\section{Discussion}

Parkinson's disease is a chronic neurodegenerative of unknown origin illness that requires regular medication unlimited in time. Several major organizations promote research and improvement of quality of life of those with the disease and their families. Parkinson's

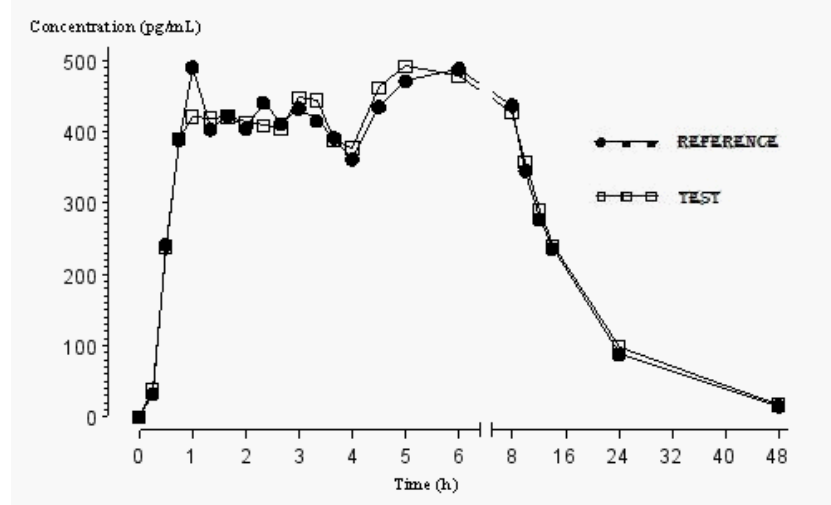

Figure 1: Mean plasma concentration -time profile of pramipexole over the first $48 \mathrm{~h}$ after oral administration of the test formulation.

\begin{tabular}{|l|c|c|c|c|}
\hline \multirow{2}{*}{ Parameters (Units) } & \multicolumn{2}{|c|}{ TEST } & \multicolumn{2}{c|}{ REFERENCE } \\
\cline { 2 - 5 } & $\begin{array}{c}\text { Means } \\
\text { (Median) }\end{array}$ & $\begin{array}{c}\text { Standard } \\
\text { Deviation } \\
\text { (Amplitude) }\end{array}$ & $\begin{array}{c}\text { Means } \\
\text { (Median) }\end{array}$ & $\begin{array}{c}\text { Standard } \\
\text { Deviation } \\
\text { (Amplitude) }\end{array}$ \\
\hline AUC $_{0-\mathrm{t}}$ (pg.h/mL) & 8201.90 & 2059.40 & 7891.56 & 1684.24 \\
\hline $\mathrm{AUC}_{0-\infty}(\mathrm{pg} . \mathrm{h} / \mathrm{mL})$ & 8574.71 & 2178.54 & 8288.01 & 1712.74 \\
\hline $\mathrm{C}_{\max }(\mathrm{pg} / \mathrm{mL})$ & 642.09 & 122.89 & 633.94 & 110.99 \\
\hline $\mathrm{T}_{\max }(\mathrm{Median} / \mathrm{Mp})(\mathrm{h})$ & 3.00 & 5.50 & 2.33 & 5.25 \\
\hline Kel(L/h) & 0.08 & 0.02 & 0.09 & 0.03 \\
\hline $\mathrm{T}_{1 / 2}(\mathrm{Median} / \mathrm{Mp})(\mathrm{h})$ & 8.65 & 10.75 & 8.19 & 8.43 \\
\hline
\end{tabular}

Table 1: Mean pharmacokinetic of parameters pramipexole of test and reference formulation.

\begin{tabular}{|l|c|c|}
\hline Parameters (Units) & TEST & REFERENCE \\
\hline & Geometrix Mean & Geometrix Mean \\
\hline AUC $_{0-\mathrm{t}}(\mathrm{pg} . \mathrm{h} / \mathrm{mL})$ & 7999.08 & 7720.36 \\
\hline $\mathrm{AUC}_{0-\infty}(\mathrm{pg} \cdot \mathrm{h} / \mathrm{mL})$ & 8370.50 & 8116.40 \\
\hline $\mathrm{C}_{\max }(\mathrm{pg} / \mathrm{mL})$ & 627.13 & 622.08 \\
\hline
\end{tabular}

Table 2: Geomatric mean pharmacokinetics parameters of pramipexole of test and references formulation.

\begin{tabular}{|l|c|c|c|c|c|}
\hline Parameters & $\begin{array}{c}\text { Ratio T/R } \\
\text { (\%) }\end{array}$ & $\begin{array}{c}\text { Lower limit } \\
\text { (\%) }\end{array}$ & $\begin{array}{c}\text { Upper limit } \\
\text { (\%) }\end{array}$ & $\begin{array}{c}\text { Power } \\
\text { (\%) }\end{array}$ & $\begin{array}{c}\text { Coefficient of } \\
\text { Variation (\%) }\end{array}$ \\
\hline AUC $_{0-\mathrm{t}}$ & 103.61 & 98.02 & 109.51 & 99.99 & 11.39 \\
\hline $\mathrm{AUC}_{0-\infty}$ & 103.03 & 97.95 & 108.59 & 99.99 & 10.59 \\
\hline $\mathrm{C}_{\max }$ & 100.81 & 93.06 & 109.21 & 99.69 & 16.49 \\
\hline $\mathrm{T}_{\max }$ (dif)(h) & 0.00 & -0.25 & 1.00 & - & - \\
\hline
\end{tabular}

Table 3: Ratios means and the $90 \%$ geometric confidence interval of test and reference formulation.

disease has a worldwide incidence and is characterized by rigidity, tremor and akinesia which is caused by the death of dopaminergic neurones in the substantia nigra of the midbrain $[8,9,10,6]$.

Dopamine agonists have been used as add-on therapy in Parkinson's disease either by increasing the efficiency or side effects of levodopa. Therapy serves as a reference substance for evaluation of new drugs. Pramipexole has been investigated as an adjunctive therapy to levodopa and as monotherapy in the treatment of Parkinson's disease. Based on numerous clinical data, efficacy profiles and safety of this non-ergoline dopamine agonist are well defined [11-16]

The pramipexole is marked by rapid and almost complete absorption, with $\mathrm{C}_{\max }$ attained within 2 hours and an absolute bioavailability $>90 \%$. Is extensively distributed and is about $15 \%$ bound to plasma proteins. Distributes into red blood cells, with an erythrocyteto-plasma ratio of about 2:1.Food intake slows the absolute rate, but not the extent, of absorption. The pharmacokinetic profile is linear with dose. Renal clearance of pramipexole is approximately three times higher than glomerular filtration. Thus, pramipexole is secreted by the renal tubules, probably by the organic cation transport system. About $90 \%$ of a dose is eliminated renally as unchanged drug. Pramipexole the elimination half-life is roughly 8 hours in young healthy adult volunteers [17].

Arguments in favor of starting a dopamine agonist rather than levodopa in early Parkinson disease have been advocated. Several phase IV randomized controlled trials have been published using the time until development of dopaminergic events as the primary outcome. These studies all show that the strategy of initial treatment with dopamine agonists delays the onset of dyskinesias and wearing off. Delaying dopaminergic events has benefits in terms of long-term 
disability and quality of life. The prevalence of dopaminergic motor complications remained higher in the initial levodopa group, suggesting a long-term benefit on the development of these complications with initial pramipexole treatment. In addition to the duodenal infusion of levodopa is invasive and inconvenient, and may be costly to maintain. Therefore, the -formulation of a dopamine agonist would be advantageous to Appear [18-21].

The bioavailability of a pharmaceutical form refers to the extent and speed of absorption of the active principle in contained it. Two pharmaceutical forms are said bioequivalent when administered to the same individual, in the same experimental conditions and at the same dose, they show no significant differences in relation to bioavailability. In this study two formulations of Pramipexole had been evaluated. Washout period was adequate and there was no quantifiable concentration of the drugs in the second period of the study, indicating that there was no carryover effect from the first to the second period. The mean ratio of parameters $\mathrm{C}_{\max }$ and $\mathrm{AUC}_{0-\mathrm{t}}$ and $90 \%$ confidence intervals of correspondents were calculated to determine the bioequivalence.

The means $\mathrm{AUC}_{0-\mathrm{t}}$ for test and reference formulation were 8201.90 pg.h/mL and 7891.56 pg.h $/ \mathrm{mL}$, for $\mathrm{AUC}_{0-\infty}$ were $8574.71 \mathrm{pg} . \mathrm{h} / \mathrm{mL}$ and $8288.01 \mathrm{pg} . \mathrm{h} / \mathrm{mL}$ and, for $\mathrm{C}_{\max } 642.09 \mathrm{pg} / \mathrm{mL}$ and $633.94 \mathrm{pg} / \mathrm{mL}$, respectively. The ratios were $103.61 \%$ for $\mathrm{AUC}_{0 \mathrm{t}}, 103.13 \%$ for $\mathrm{AUC}_{0}$ $\infty$ and $100.81 \%$ for $\mathrm{C}_{\max }$. The $90 \%$ confidence intervals were $98.02-$ $109.51 \%$ for $\mathrm{AUC}_{0-\mathrm{t}}, 97.95-108.59 \%$ for $\mathrm{AUC}_{0-\infty}$ and $93.06-109.21 \%$ for $\mathrm{C}_{\max }$.

The $\mathrm{AUC}_{0-\mathrm{t}}$ and $\mathrm{AUC}_{0-\infty}$ are both recognized as an uncontaminated measurement of the extent of absorption. The present study showed that $90 \% \mathrm{CI}$ of mean $\mathrm{AUC}_{0-\mathrm{t}}$ and $\mathrm{AUC}_{0-\infty}$ (after log-transformation of individual ratios) were included into the bioequivalence range (80-125\%), consequently, the two formulations of Pramipexole are equivalent for the extend of absorption.

The statistical comparison of $\mathrm{C}_{\max }, \mathrm{AUC}_{0-\mathrm{t}}$ and $\mathrm{AUC}_{0-\infty}$ clearly indicated no significant difference in the two formulations of Pramipexole $0.125 \mathrm{mg}$ tablet. $90 \%$ confidence intervals for the mean ratio (T/R) of $\mathrm{C}_{\max }, \mathrm{AUC}_{0-\mathrm{t}}$ and $\mathrm{AUC}_{0-\infty}$ were entirely within the US Food and Drug Administration acceptance range. Based on the pharmacokinetic and statistical results of this study, we can conclude that pramipezan ${ }^{\circledR}$ (pramipexole) $0.125 \mathrm{mg}$ tablet, manufactured by Cobalt Pharmaceuticals, Canada/ Arrow Farmacêutica Ltda* is bioequivalent to Sifrol ${ }^{\circledR} 0.125 \mathrm{mg}$ tablet (Boehringer Ingelheim, Brazil), and that then the test product can be considered interchangeable in medical practice.

\section{Acknowledgments}

This research work was financially supported by Arrow Farmacêutica Ltda.

\section{References}

1. Hughes AJ, Daniel SE, Blankson S, Lees AJ (1993) A clinicopathologic study of 100 cases of Parkinson's disease. Arch Neurol 50: 140-148.

2. Eriksen JL, Wszolek Z, Petrucelli L (2005) Molecular pathogenesis of Parkinson disease. Arch Neurol 62: 353-357.

3. Samii A, Nutt JG, Ransom BR (2004) Parkinson's disease. Lancet 363: 1783 1793.

4. Lesage S, Brice A (2009) Parkinson's disease: from monogenic forms to genetic susceptibility factors. Hum Mol Genet 18: 48-59.

5. Piercey MF (1998) Pharmacology of pramipexole, a dopamine D3-preferring agonist useful in treating Parkinson's disease. Clin Neuropharmacol 21: 141151
6. Gottwald MD, Bainbridge JL, Dowling GA, Aminoff MJ, Alldredge BK (1997) New pharmacotherapy for Parkinson's disease. Ann Pharmacother 31: 12051217.

7. Lange KW (1998) Clinical pharmacology of dopamine agonists in Parkinson's disease. Drugs Aging 13: 381-389.

8. Lang AE, Lozano AM (1998) Parkinson's disease. First of two parts. N Engl J Med 339: 1044-1053.

9. Lang AE, Lozano AM (1998) Parkinson's disease. Second of two parts. N Eng J Med 339: 1130-1143.

10. Schapira AHV (1999) Science, medicine, and the future: Parkinson's disease. BMJ 318:311-314

11. Grosset KA, Bone I, Grosset DG (2005) Suboptimal medication adherence in Parkinson's disease. Mov Disord 20:1502-1507.

12. Moller JC, Oertel WH (2005) Pramipexole in the treatment of Parkinson's disease: new developments. Expert Rev Neurother 5: 581-586.

13. Pinter MM, Pogarell O, Oertel WH (1999) Efficacy, safety, and tolerance of the non-ergoline dopamine agonist pramipexole in the treatment of advanced Parkinson's disease: a double blind, placebo controlled, randomised, multicentre study. J Neurol Neurosurg Psychiatry 66: 436-441.

14. Shannon KM, Bennett JP Jr, Friedman JH (1997) Efficacy of pramipexole, a novel dopamine agonist, as monotherapy in mild to moderate Parkinson's disease. The Pramipexole Study Group. Neurology 49:724-728.

15. Anonymous (1997) Safety and efficacy of pramipexole in early Parkinson disease. A randomized dose-ranging study. JAMA 278: 125-130.

16. Hubble JP, Koller WC, Cutler NR, Sramek JJ, Friedman J, et al. (1995 Pramipexole in patients with early Parkinson's disease. Clin Neuropharmaco 18: 338-347.

17. Hubble JP (2000) Pre-clinical studies of pramipexole: Clinical relevance. Eur J Neurol 7: 15-20.

18. Rascol O, Brooks DJ, Korczyn AD, De Deyn PP, Clarke CE, et al. (2000) A five-year study of the incidence of dyskinesia in patients with early Parkinson's disease who were treated with ropinirole or levodopa. N Engl J Med 342: 14841491.

19. Nilsson D, Hansson LE, Johansson K, Nyström C, Paalzow L, et al. (1998) Long-term intraduodenal infusion of a water based levodopa-carbidopa dispersion in very advanced Parkinson's disease. Acta Neurol Scand 97: 175183

20. Stocchi F, Vacca L, Ruggieri S, Olanow CW (2005) Intermittent vs continuous levodopa administration in patients with advanced Parkinson disease: A clinical and pharmacokinetic study. Arch Neurol 62: 905-910.

21. DeBattista C, Solvason HB, Breen JA, Schatzberg AF (2000) Pramipexole augmentation of a selective serotonin reuptake inhibitor in the treatment of depression. J Clin Psychopharmacol 20: 274-275. 